\title{
Studies on Genetic Variations of Males and Females of Bactrocera zonata (Diptera: Tephritidae) Collected from Different Regions in Egypt Neima K. Al-Senosy ${ }^{1}$ and Faten A. A. Badr ${ }^{2}$ \\ ${ }^{1}$ Department of Genetics, Faculty of Agriculture, Ain Shams University, Egypt. \\ ${ }_{2}^{2}$ Plant Protction Research Institute, Agricultural Research Center, Dokki, Giza, Egypt.
}

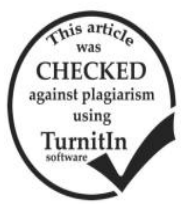

\section{ABSTRACT}

The present study aims to determine the level of malatox resistance in peach fruit fly (Bactrocera zonata).The surface film petri dish technique and molecular markers such as Random Amplified Polymorphic DNA (RAPD) and Inter-Simple Sequence Repeats (ISSR) were used to make fingerprinting. Adult flies collected from different areas in Egypt; Siwa Oasis, Assiut, Ismailia, Kafr-Elsheikh and Giza were compared to the laboratory strain. The laboratory strain was tested with the organophosphorus insecticide (malatox) with surface film petri dish technique to estimate the concentration mortality lines. An approximate $\mathrm{LC}_{99}$ value was selected to discriminate for resistance in five field colony populations. Data revealed that individuals collected from Siwa fields exhibited the highest resistance value to malatox followed descendengly by individuals of Assiut, Ismailia, Kafr-Elsheikh and Giza, respectively. RAPD analysis of malatox resistant of $B$. zonata flies showed considerable differences, the five primers detected a total of 176 bands, with an average of 35.2 bands per primer and percentage of polymorphism ranged from $66 \%(\mathrm{P} 13)$ to $100 \%$ (C16). Similarly, ISSR marker gave $100 \%$ polymorphism among the five studied primers, produced 161bands with an average of 32.2 bands per primer and found to be potential markers for resistant.These results suggested that malatox treatment created genetic alterations in field $B$. zonata flies and that may be a reason to initiate or create resistant strains from this dangerous insect pest.

\section{INTRODUCTION}

The peach fruit fly $B$. zonata (Diptera: Tephritidae) is one of the most harmful pests. This insect is a quarantine pest in many countries over the world. In India, it causes a huge loss in fruits (Grewal and Malhi, 1987). In Egypt, $B$. zonata showed high levels and rates of infestation (ElMinshawy et al., 1999). This pest widly distributed in Qalubia and North Sinai (Hashem et al., 2001), Elbehera (Draz et al., 2002) and Nile Delta and whole Nile Valley (EPPO, 2002 and Abdel-Galil, 2007).

Pesticide of the oraganophosphorus group (malatox) is mainly used to reduce spread of this pest. The wide use of chemical insecticides causes many environmental hazards or problems as pest-resistance to pesticides that has been recognized by the study of biochemical aspects.

Polymerase Chain Reaction (PCR) is a useful tool in many applications in biotechnology. Random amplified polymorphic DNA polymerase chain reaction (RAPD PCR) has been used to differentiate various insect species and their resistance strains. This technique applied to identify different populations within a species. The technique is quick and easy to detect nucleotide sequence polymorphisms using a single primer of arbitrary nucleotide sequence (Welsh and McClelland, 1990 and Williams et al., 1990). RAPD markers are used to determine the insecticide resistance genes in insects (Jain et al., 2010). Patel et al. (2014) reported that RAPD-PCR technique is useful to study the Rynaxypyr resistance in Plutella xylostella. Moreover, RAPD marker was used to evaluate the imidacloprid resistance in cotton whitefly (Sharma et al., 2008). Heckel et al. (1995) showed that RAPD protocol produce a suitable number of DNA markers to study the genes responsible for the differences in Bacillus thuringiensis resistance in strains of Diamondback Moth. Inter-Simple Sequence Repeats (ISSR) permits to detect polymorphisms in intermicrostallite loci, using a primer designed from dinucleotide or trinucleotide simple sequence repeats ( $\mathrm{Li}$ and $\mathrm{Xia}, 2005$ ). Shouhani et al. (2014) mentioned that ISSR marker is a suitable technique in the honey bee for detection of polymorphism, and ISSR bands in numerous iterations on various breeds are highly repeatable in comparison with other molecular techniques. ISSR markers offer higher reproducibility than randomly amplified polymorphic DNA due to the use of longer primers and higher annealing temperature. Moreover, ISSR is a powerful technique for fingerprinting black fly species (Dušinsky et al., 2006). ISSR markers have the advantage of requiring no prior information of DNA sequence of the target species and producing fragments with higher reproducibility than RAPD markers (Costa et al., 2016).

Polymorphisms revealed by the ISSR method can result from insertions or deletions within the genomic fragment flanked by microsatellites, or from single base differences in the priming region, which can be discriminated by dissimilar templates. The information content for this type of amplification assay is high becauseall these potential sources of polymorphism can be detected in the entire genome (Leroy and Leon, 2000).

This work amid to study insecticide-resistance levels in both males and females of different populations of the peach fruit fly, B. zonata collected from various regions in Egypt using RAPD-PCR and ISSR techniques to determine genetic variations and resistance for the field populations.

\section{MATERIALS AND METHODS}

\section{Test Insects}

Laboratory colony continuously reared in the Horticultural Insects Research Department, Plant Protection Research Institute, Agricultural Research Center, Dokki, Giza under constant conditions at temperature of $30 \pm 1^{\circ} \mathrm{C}$ and $70 \pm 5 \%$ R. H. was obtained. Adults were provided with water as well as sugar and fortified protein hydrolyze at a ratio of 10:1, respectively. Five field populations of peach fruit fly $B$. zonata were isolated from heavely infested fruits collected from mango orchards in Assuit, Giza, KafrElsheikh, Siwa and Ismailia districts during the season of 2016. These orchards were regularly treated with insecticides according to recommendations of the Ministry of Agriculture. (Malatox incorporated with Buminal as food attractant).

Discrimination concentration technique was used for rapid monitoring of the insecticidal resistance in fieldcollected B. zonata. Roush and Miller (1986) calculated that testing all of an insect sample at a discriminating concentration is more efficient that estimating dose-response 
regression lines in monitoring for resistance. The diagnostic concentration is a single concentration that can discriminate between susceptible and resistant individuals. Gunning et al. (1984) suggested that the discriminating concentration was the $\mathrm{LC}_{99}$ values for susceptible insects.. The $\mathrm{LC}_{99}$ of the Laboratory strain of $B$. zonata flies were previously estimated via probit analysis and used to estimate a diagnostic concentration for Malatox 57\% tested, based on considerations discussed by Roush and Miller (1986). To estimate a concentration that would reliably cause approximately $99 \%$ flies mortality of the $B$. zonata susceptible strain, $2 \mathrm{ml}$ of the insecticidal solution was pipetted into a petri-dish, the petri-dish was rolled for approximately $2 \mathrm{~min}$ to ensure that all surfaces received the insecticidal treatment. Petri-dishes were air dried at room temperature for 25 hours. Ten flies were placed in each petri dish. The experiment was replicated four times. The mortality percentages were assessed after 24 hours. Resistance percentages in the field colony treated with malatox were determined by calculating mortality percentages of the discrimination concentration of malatox compared to Laboratory mortality and percentages of survival in Laboratory insect at the discrimination concentration was used.

${ }^{*}$ Resistance $=100-\frac{\% \text { mortality at discriminating concentration field }}{\text { mortalityat discriminating concentration in laboratorystrain }} \times 100$

${ }^{*}$ Relative resistance $=\frac{\text { the highest resistance percentage }}{\text { Corresponding resistance percentage of each strain }}$

\section{Molecular Genetic Techniques}

\section{1- DNA extraction}

DNA was extracted using phenol/chloroform extraction method (Moreau, 2014). For total DNA isolation, adult fly weighing about 50 to $100 \mathrm{mg}$ were throuoghly macerated with micro pestle in a $1.5 \mathrm{~mL}$ Eppendorf microcentrifuge tube containing $500 \mu \mathrm{L}$ of grinding homogenizing buffer followed by $25 \mu \mathrm{L}$ of $20 \%$ SDS, $20 \mu \mathrm{L}$ of $20 \mathrm{mg} / \mathrm{mL}$ proteinase $\mathrm{K}, 100 \mu \mathrm{L}$ of $0.5 \mathrm{M}$ EDTA and $50 \mu \mathrm{L}$ of $0.1 \mathrm{M}$ Tris (pH8.0).

The homogenate was incubated at $55^{\circ} \mathrm{C}$ for 3 hours or overnight. Then $550 \mu \mathrm{L}$ of phenol was added, shaked as vortex for 1 minute and microcentrifuged for 5-10 minutes. The supernatant (wich contains DNA) was taken and placed in new tubes. The old tubes were discarded. The previous steps were repeated 2-3 times, or til the cloudy color of supernatant disappeared. Afterthat, $500 \mu \mathrm{L}$ of chloroform were added to each sample, vortex for 1 minute and microcentrifuged for 5-10 minutes. Then, the supernatant was taken, placed in new labeled tubes, discarded the old tubes and repeated these steps 5-7 times again (optional). Hence, $750 \mu \mathrm{L}$ of cold $100 \% \mathrm{EtOH}$ were added to the supernatant kept for 2 hours at $20^{\circ} \mathrm{C}$ (can be overnight). Then, samples, microcentifuged for 10 minutes to pellet DNA and then gently discarded the supernatant by slowly pouring it off, leaving only the pellet.

The pellet was washed with $70 \%$ ethanol dried and finally resuspended in $300-500 \mu \mathrm{L}$ sterile distilled water. Quality of DNA was assessed by agarose gel electrophoresis $(0.7 \%$ prepared in TAE buffer) that was of highmolecular weight with DNA band near the wells and no streaking or RNA band. DNA concentration assessed at $260 \mathrm{~nm}$ in spectrophotometer.

2- Random Amplified Polymorphic DNA (RAPDPCR) amplification

A list of 5 primers used in this study is shown in Table (1) (Operon Technologies Inc., USA). The PCR reactions were performed in a final volume of $25 \mu \mathrm{l}$

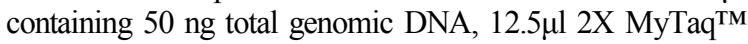
Red Mix kit (BIOLINE catalog N. BIO-25043) and $50 \mathrm{p}$ mole primer. The PCR cycling parameters consisted of an initial denaturation at $92^{\circ} \mathrm{C}$ for $5 \mathrm{~min}$, followed by 40 cycles of denaturation at $92^{\circ} \mathrm{C}$ for 30 seconds, annealing at $35^{\circ} \mathrm{C}$ for $1 \mathrm{~min}$, ramp up to $72^{\circ} \mathrm{C}$ for $5 \mathrm{~min}$, extension at $72^{\circ} \mathrm{C}$ for 2 min and a final extension at $72^{\circ} \mathrm{C}$ for $10 \mathrm{~min}$. The amplified PCR fragments were separated on $1.5 \%$ agarose gel in $1 \mathrm{x}$ TAE buffer (40 mMTris-acetate, $1.74 \mathrm{M}$ of glacial acetic acid and $1 \mathrm{mM}$ EDTA, $\mathrm{pH} 8.3$ at $25^{\circ} \mathrm{C}$ ), stained with ethidium bromide $(0.5 \mu \mathrm{g} / \mathrm{ml})$ and visualized by Gel documentation (G:BOX) (SYNGENE model 680XHR, UK).

\section{3- Inter Simple Sequence Repeats (ISSR-PCR) amplification}

A total of 5 primers appeared in Table (1). The PCR reactions were performed in a final volume of $25 \mu \mathrm{l}$ containing $50 \mathrm{ng}$ total genomic DNA, 12.5ul 2X MyTaq ${ }^{\mathrm{TM}}$ Red Mix kit (BIOLINE catalog N. BIO-25043) and 50 pmole primer. The PCR cycling parameters consisted of an initial denaturation at $95^{\circ} \mathrm{C}$ for 5 min followed by 40 cycles of denaturation at $95^{\circ} \mathrm{C}$ for 30 seconds, annealing at $54^{\circ} \mathrm{C}$ for $1 \mathrm{~min}$, extension at $72^{\circ} \mathrm{C}$ for $2 \mathrm{~min}$ and a final extension at $72^{\circ} \mathrm{C}$ for $10 \mathrm{~min}$. The amplified PCR fragments were separated on $1.5 \%$ agarose gel.

Data Analysis

DNA fragment sizes were used to assign loci for each primer. Bands were scored as diallelic for each assigned locus ( 1 =band present; $0=$ band absence) using GelAnalyzer 2010 program.

Table 1. List of RAPD and ISSR primers used and their sequences.

\begin{tabular}{|c|c|c|c|c|c|}
\hline \multirow{6}{*}{ RAPD primers } & Name & Sequence & \multirow{6}{*}{ ISSR primers } & Name & Sequence \\
\hline & $\mathrm{C} 1$ & TTCGAGCCAG & & UBC811 & GAGAGAGAGAGAGAGAC \\
\hline & P13 & GGAGTGCCTC & & UBC-834 & GAGAGAGAGAGAGAGAGAGAT \\
\hline & B12 & CCTTGACGCA & & UBC849 & GAGAGAGAGAGAGAGAT \\
\hline & $\mathrm{C} 16$ & CACACTCCAG & & UBC-823 & ТСТСТСТСТСТСТСТСС \\
\hline & $\mathrm{C} 18$ & TGAGTGGGTG & & UBC- 843 & CTCTCTCTCTCTCTCTRA \\
\hline
\end{tabular}

\section{Similarity Index}

The similarity indices were used to compare the patterns between populations. This index reflects the extent of bands sharing (Nei and Li, 1979) calculated as :

$$
2 \mathbf{N}_{\mathrm{ab}} /\left(\mathbf{N}_{\mathrm{a}}+\mathbf{N}_{\mathrm{b}}\right)
$$

Where: $N_{a b}$ is the number of bands common to individuals $a$ and $b$. $N_{a}$ and $N_{b}$ are total number of bands in a and $b$, respectively.

\section{Resistance Levels}

Data in Table (2) show mortality \% in males and females of $B$. zonata at different concentrations of malatox (2000, 1000, 500, 250, 125 and $62.5 \mathrm{ppm})$. 
Table 2. Effectiveness of malatox against male and female flies of Bactrocera zonata in the laboratory strain.

\begin{tabular}{|c|c|c|}
\hline \multirow{2}{*}{$\begin{array}{l}\text { Concentration } \\
\text { (ppm) }\end{array}$} & \multicolumn{2}{|c|}{ Mortality \% } \\
\hline & $0^{\pi}$ & O \\
\hline 2000 & 96.7 & 94.6 \\
\hline 1000 & 91.1 & 87.1 \\
\hline 500 & 73.4 & 70.9 \\
\hline 250 & 67.3 & 52.9 \\
\hline 125 & 54.8 & 41 \\
\hline 62.5 & 42.8 & 36.1 \\
\hline Slope & 1.323 & 1.366 \\
\hline $\mathrm{LC}_{50}$ & 104.63 & 174.71 \\
\hline $\mathrm{LC}_{99}$ & 6036.72 & 8872.04 \\
\hline
\end{tabular}

The mortality $\%$ was higher in males than in females at all used concentrations. The $\mathrm{LC}_{50}$ values were 104.63 and 174.71 for males and females, respectively. The $\mathrm{LC}_{99}$ values were 6036.72 for males and 8872.04 for females. Data in Table (3), illustrate the response of the adult of males and females of $B$. zonata to malatox under five different geomorphological areas Siwa, Assiut, Ismailia, KafrElsheikh and Giza. Generally, males were slightly more susceptible than females recording lower levels in resistance than females of all tested areas. The highest mortality was recorded for Giza, while the lowest one was optained for Siwa. The resistance \% in B. zonata can be descendingly ordered as those of Siwa, Assiut, Ismailia, Kafr-Elsheikh and Giza (Table, 3). Relative resistance varied from 1 in males and females of Siwa to 2.05 in males of Giza.

B. zonata (peach fruit fly), is considered one of the most damaging fruit pests in various areas of the world (Drew, 1989). Also, Shehata et al.(2008) stated that peach fruit fly registered in several regions in Egypt where it caused great problems to many fruits. Dukre et al. (2009) mentioned that catalyses and esterases enzymes play an important role in detoxification of the insecticides in insect body. Thus, these two enzymes catalyse and esterase are associating with resistance in insects.Yaqoob et al. (2013)

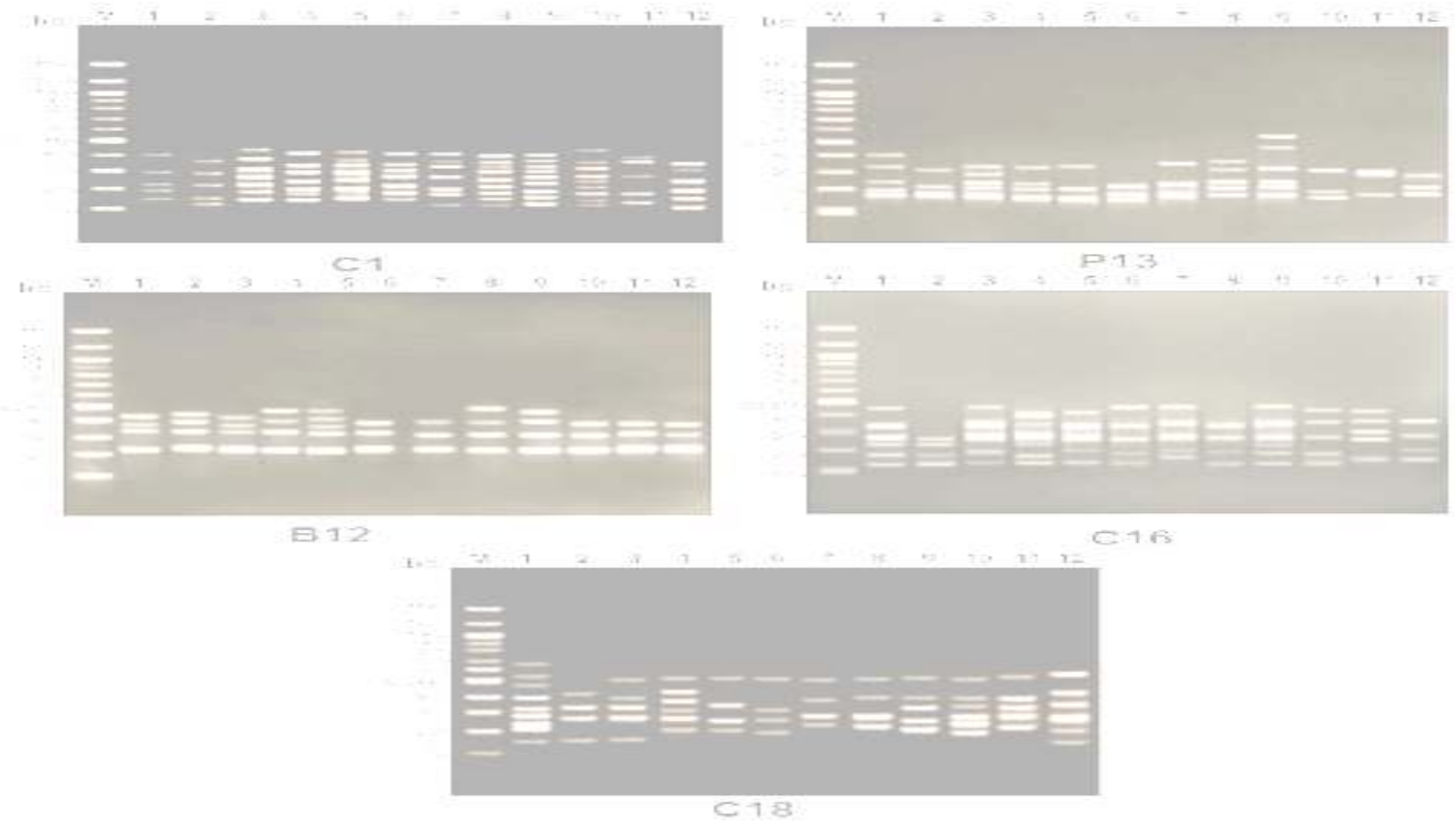

Fig.1. RAPD fingerprints and markers of Bactrocera zonata compared with laboratory strain. Marker (M); laboratory strain (1,2); Giza $(3,4)$; Kfer-Elsheih $(5,6)$; Assiut $(7,8)$; Siwa $(9,10)$ and Ismailia $(11,12)$. suggested that increase in levels of esterases, glutathione-Stransferesaes and monooxygenases are involved in insecticide resistance mechanism in B. zonata.

Table 3. Response of males and females of Bactrocera zonata collected from different regions to discriminating concentration of malatox.

\begin{tabular}{|c|c|c|c|c|c|c|}
\hline \multirow[t]{2}{*}{ Region } & \multicolumn{2}{|c|}{$\begin{array}{c}\text { Mortality } \\
\%\end{array}$} & \multicolumn{2}{|c|}{$\begin{array}{c}\text { Resistance } \\
\%\end{array}$} & \multicolumn{2}{|c|}{$\begin{array}{c}\text { Relative } \\
\text { resistance }\end{array}$} \\
\hline & $0^{1}$ & 웅 & $0^{\pi}$ & 웅 & d & ㅇ \\
\hline wa & 38 & 33.4 & 51.62 & 66.2 & 1.00 & 1.00 \\
\hline & 43.5 & 3. & & & 0 & 1.10 \\
\hline & 70 & 46 & & & 1.20 & 1.23 \\
\hline fer-E & 63.3 & 58.9 & 36.06 & 40.51 & 1.71 & 1.64 \\
\hline iza & 69.2 & 62.7 & 30.10 & 36.67 & 2.05 & 1.81 \\
\hline
\end{tabular}

\section{Molecular Techniques}

Five pre-selected RAPD primers and five ISSR primers exhibited polymorphisms among the five different populations of B. zonata males and females (Giza, KafrElsheikh, Assiut, Ismailia and Siwa) compared to laboratory strain.

Random amplified polymorphic DNA (RAPD) analysis

In this study, the number and size of fragments showed different polymorphism among the tested populations as a result of PCR amplification. Identical sized bands were observed among different strains (similarity). RAPD-PCR analysis was useful in describing any show in the genomic of these strains. Five primers of arbitrary sequences were used to screen pooled genomic DNA of five different strains of B. zonata males and females comparing to the laboratory strain.

In Fig. (1) and Table (4), the fingerprints generated by primer $\mathrm{C} 1$ revealed highly resistance levels in males of Giza, Kafr-elsheikh and Siwa populations where the similarity index values equal 0.00 compared to laboratory strain. 
Table 4. Estimated similarity index between males and females of field populations of Bactrocera zonata compared to laboratory strains using primer $\mathrm{C} 1$ assessed by RAPD.

\begin{tabular}{|c|c|c|c|c|c|c|c|c|c|c|c|c|}
\hline \multicolumn{7}{|c|}{ Males } & \multicolumn{6}{|c|}{ Females } \\
\hline Strains & Lab & Giza & KafrEl-sheikh & Assiut & Swia & Ismailia & Lab & Giza & KafrEl-sheikh & Assiut & Siwa & Ismailia \\
\hline Laboratory & - & 0.00 & 0.33 & 0.40 & 0.00 & 0.33 & - & 0.80 & 1.0 & 1.0 & 0.40 & 0.80 \\
\hline Giza & - & - & 0.00 & 0.50 & 0.00 & 0.00 & - & - & 0.80 & 0.80 & 0.57 & 0.67 \\
\hline KafrEl-sheikh & - & - & - & 0.40 & 0.00 & 0.33 & - & - & - & 1.00 & 0.67 & 0.80 \\
\hline Assiut & - & - & - & - & 0.00 & 0.40 & - & - & - & - & 0.67 & 0.80 \\
\hline Siwa & - & - & - & - & - & 0.00 & - & - & - & - & - & 0.57 \\
\hline Ismailia & - & - & - & - & - & - & - & - & - & - & - & - \\
\hline
\end{tabular}

On the other hand, there were variations in 724editerran index among popuations of the studied regions that ranged between 0.00 to 0.50 . In case female flies, the highest resistance level was noticed between the laboratory and Siwa populations (Table, 4) where the similarity index value recorded 0.40 . While, the lowest resistance level observed between laboratory strain and both Giza and Ismailia populations where the similarity index value was 0.80 . The similarity index values among the field strains ranged between 0.33 and 1.00 .

According to RAPD-PCR the fingerprint generated by primer P13 clarified the similarity index values which ranged from 0.57 to 1.00 in males, while the range differed from 0.75 to 1.00 in females of the tested populations compared to the laboratory strain as shown in table (5).

Table 5. Estimated similarity index between males and females of field populations of Bactrocera zonata compared to laboratory strain using primer P13 assessed by RAPD.

\begin{tabular}{|c|c|c|c|c|c|c|c|c|c|c|c|c|}
\hline \multicolumn{7}{|c|}{ Males } & \multicolumn{6}{|c|}{ Females } \\
\hline Strains & Lab & Giza & Kafr El-sheikh & Assiut & Swia & Ismailia & Lab. & Giza & Kafr El-sheikh & Assiut & Siwa & Ismailia \\
\hline$\overline{\mathrm{Lab}}$ & - & 0.86 & 0.86 & 1.00 & 0.86 & 1.00 & - & 0.75 & 0.86 & 0.75 & 0.86 & 0.86 \\
\hline Giza & - & - & 0.75 & 0.86 & 0.75 & 0.75 & - & - & 0.86 & 0.75 & 0.86 & 0.86 \\
\hline KafrEl-sheikh & - & - & - & 0.86 & 0.75 & 0.86 & - & - & - & 0.86 & 1.00 & 1.00 \\
\hline Assiut & - & - & - & - & 0.86 & 1.00 & - & - & - & - & 0.86 & 0.86 \\
\hline Siwa & - & - & - & - & - & 0.57 & - & - & - & - & - & 1.00 \\
\hline Ismailia & - & - & - & - & - & - & - & - & - & - & - & - \\
\hline
\end{tabular}

The fingerprint generated by primer B12 compiled in Table (6) show that similarity index values ranged from 0.33 to 0.75 among males of the tested populations, while the values ranged between 0.00 and 0.80 in case of females of the same populations of the peach fruit fly, B. zonata.

Data in Table (7) show that similarity index values, assessed by RAPD using primer C16, differed between the used populations and ranged from 0.33 to 0.67 in case of males, but in case if the peach fruit fly females, the similarity index values ranged between $0.00-0.80$.

In Table (8) the similarity index values assessed by RAPD using primer C18 differently varied between the tested poplations and ranged between 0.44 and 0.67 in males of the peach fruit fly and 0.50 to 1.00 in females. Data showed low resistance levels in populations collected from all regions compared to the laboratory strain.

Table 6. Estimated similarity index between males and females of field populations of Bactrocera zonata compared to laboratory strain using primer B12 assessed by RAPD.

\begin{tabular}{|c|c|c|c|c|c|c|c|c|c|c|c|c|}
\hline \multicolumn{7}{|c|}{ Males } & \multicolumn{6}{|c|}{ Females } \\
\hline Strains & Lab. & Giza & KafrEl-sheikh & Assiut & Swia & Ismailia & Lab. & Giza & KafrEl-sheikh & Assiut & Siwa & Ismailia \\
\hline Laboratory & - & 0.57 & 0.33 & 0.40 & 0.57 & 0.75 & - & 0.0 & 0.0 & 0.0 & 0.0 & 0.0 \\
\hline Giza & - & - & 0.40 & 0.50 & 0.67 & 0.57 & - & - & 0.0 & 0.80 & 0.67 & 0.57 \\
\hline KafrEl-sheikh & - & - & - & 0.67 & 0.40 & 0.33 & - & - & - & 0.67 & 0.50 & 0.40 \\
\hline Assiut & - & - & - & - & 0.50 & 0.40 & - & - & - & - & 0.80 & 0.67 \\
\hline Siwa & - & - & - & - & - & 0.57 & - & - & - & - & - & 0.57 \\
\hline Ismailia & - & - & - & - & - & - & - & - & - & - & - & - \\
\hline
\end{tabular}

Table 7. Estimated similarity index between males and females of field populations of Bactrocera zonata compared to laboratory strain using primer $\mathrm{C16}$ assessed by RAPD.

\begin{tabular}{|c|c|c|c|c|c|c|c|c|c|c|c|c|}
\hline \multicolumn{7}{|c|}{ Males } & \multicolumn{6}{|c|}{ Females } \\
\hline Strains & Lab. & Giza & KafrEl-sheikh & Assiut & Swia & Ismailia & Lab. & Giza & KafrEl-sheikh & Assiut & Siwa & Ismailia \\
\hline Laboratory & - & 0.57 & 0.33 & 0.40 & 0.57 & 0.75 & - & 0.0 & 0.0 & 0.0 & 0.0 & 0.0 \\
\hline Giza & - & - & 0.40 & 0.50 & 0.67 & 0.57 & - & - & 0.0 & 0.80 & 0.67 & 0.57 \\
\hline KafrEl-sheikh & - & - & - & 0.67 & 0.40 & 0.33 & - & - & - & 0.67 & 0.50 & 0.40 \\
\hline Assiut & - & - & - & - & 0.50 & 0.40 & - & - & - & - & 0.80 & 0.67 \\
\hline Siwa & - & - & - & - & - & 0.57 & - & - & - & - & - & 0.57 \\
\hline Ismailia & - & - & - & - & - & - & - & - & - & - & - & - \\
\hline
\end{tabular}

Table 8. Estimated similarity index between males and females of field populations of Bactrocera zonata compared to laboratory strain using primer $\mathrm{C18}$ assessed by RAPD.

\begin{tabular}{|c|c|c|c|c|c|c|c|c|c|c|c|c|}
\hline \multicolumn{7}{|c|}{ Males } & \multicolumn{6}{|c|}{ Females } \\
\hline Strains & Lab. & Giza & KafrEl-sheikh & Assiut & Swia & Ismailia & Lab. & Giza & KafrEl-sheikh & Assiut & Siwa & Ismailia \\
\hline Laboratory & - & 0.67 & 0.67 & 0.67 & 0.57 & 0.67 & - & 1.00 & 0.80 & 0.57 & 0.80 & 0.80 \\
\hline Giza & - & - & 0.50 & 0.50 & 0.44 & 0.50 & - & - & 0.80 & 0.57 & 0.80 & 0.80 \\
\hline KafrEl-sheikh & - & - & - & 0.50 & 0.44 & 0.57 & - & - & - & 0.50 & 0.67 & 0.67 \\
\hline Assiut & - & - & - & - & 0.44 & 0.50 & - & - & - & - & 0.50 & 0.50 \\
\hline Siwa & - & - & - & - & - & 0.44 & - & - & - & - & - & 0.67 \\
\hline Ismailia & - & - & - & - & - & - & - & - & - & - & - & - \\
\hline
\end{tabular}


Inter-Simple Sequence Repeats (ISSR-PCR)

The percentage of polymorphism was $100 \%$ in all primers. According to ISSR and Table 3, the highest resistance level was observed in the population of of Siwa males and the lowest level was found in the population of Giza males flies comparing to the laboratory strain (Table, 9).

Moreover, in Table (10), the populations of Giza, Kafr-Elsheikh, Siwa and Ismailia showed high resistance levels compared to the laboratory strain in males. But, in case of female flies, individuals of the populations of Giza, Assuit, Siwa and Ismailia recorded the high resistance levels. Also, ISSR amplification revealed high resistance levels in male flies of the five field populations comparing to the laboratory strain.
The similarity index values ranged between 0.00 and 0.40 . In case of female flies, the highest resistance level appeared in Giza, Assuit and Siwa strains compared to the laboratory strain where the similarity index values ranged between 0.00 and 0.40 (Table, 11).

The same trend was obtained with primer UBC- 823 to determine the resistance level between the tested populations assessed by ISSR (table, 12).

The opposite appeared in ISSR amplification which revealed high resistance levels in all tested field populations among male flies. Also, high resistance levels appeared at all field populations, except in the population collected from Siwa that recorded low resistance level compared to the laboratory strain (Table 13).

Table 9. Estimated similarity index between males and females of field populations of Bactrocera zonata compared to the laboratory strain using primer UBC811 assessed by ISSR.

\begin{tabular}{|c|c|c|c|c|c|c|c|c|c|c|c|c|}
\hline & \multicolumn{6}{|c|}{ Males } & \multicolumn{6}{|c|}{ Females } \\
\hline Strains & Lab. & Giza & KafrEl-sheikh & Assiut & Swia & Ismailia & Lab. & Giza & KafrEl-sheikh & Assiut & Siwa & Ismailia \\
\hline Laboratory & - & 0.40 & 0.20 & 0.20 & 0.00 & 0.20 & - & 0.15 & 0.15 & 0.17 & 0.00 & 0.17 \\
\hline Giza & - & - & 0.40 & 0.20 & 0.00 & 0.40 & - & - & 0.33 & 0.00 & 0.00 & 0.18 \\
\hline KafrEl-sheikh & - & - & - & 0.20 & 0.25 & 0.40 & - & - & - & 0.00 & 0.00 & 0.55 \\
\hline Assiut & - & - & - & - & 0.00 & 0.20 & - & - & - & - & 0.00 & 0.40 \\
\hline Siwa & - & - & - & - & - & 0.00 & - & - & - & - & - & 0.00 \\
\hline Ismailia & - & - & - & - & - & - & - & - & - & - & - & - \\
\hline
\end{tabular}

Table 10. Estimated similarity index between males and females of field populations of Bactrocera zonata compared to the laboratory strain using primer UBC-834 assessed by ISSR.

\begin{tabular}{|c|c|c|c|c|c|c|c|c|c|c|c|c|}
\hline \multicolumn{7}{|c|}{ Males } & \multicolumn{6}{|c|}{ Females } \\
\hline$\overline{\text { Strains }}$ & Lab. & Giza & KafrEl-sheikh & Assiut & Swia & Ismailia & Lab. & Giza & KafrEl-sheikh & Assiut & Siwa & Ismailia \\
\hline Laboratory & - & 0.00 & 0.00 & 0.25 & 0.00 & 0.00 & - & 0.00 & 0.33 & 0.00 & 0.00 & 0.00 \\
\hline Giza & - & - & 0.00 & 0.00 & 0.00 & 0.00 & - & - & 0.00 & 0.00 & 0.00 & 0.00 \\
\hline KafrEl-sheikh & - & - & - & 0.00 & 0.00 & 0.00 & - & - & - & 0.00 & 0.00 & 0.00 \\
\hline Assiut & - & - & - & - & 0.00 & 0.00 & - & - & - & - & 0.00 & 0.00 \\
\hline Siwa & - & - & - & - & - & 0.00 & - & - & - & - & - & 0.00 \\
\hline Ismailia & - & - & - & - & - & - & - & - & - & - & - & - \\
\hline
\end{tabular}

Table 11. Estimated similarity index between males and females of field populations of Bactrocera zonata compared to the laboratory strain using primer UBC849 assessed by ISSR.

\begin{tabular}{|c|c|c|c|c|c|c|c|c|c|c|c|c|}
\hline & & & Males & & & & \multicolumn{6}{|c|}{ Females } \\
\hline Strains & Lab. & Giza & KafrEl-sheikh & Assiut & Siwa & Ismailia & Lab. & Giza & KafrEl-sheikh & Assiut & Siwa & Ismailia \\
\hline Laboratory & - & 0.00 & 0.00 & 0.00 & 0.00 & 0.00 & - & 0.00 & 0.40 & 0.00 & 0.00 & 0.33 \\
\hline Giza & - & - & 0.40 & 0.00 & 0.00 & 0.00 & - & - & 0.00 & 0.00 & 0.00 & 0.00 \\
\hline KafrEl-sheikh & - & - & - & 0.00 & 0.00 & 0.00 & - & - & - & 0.00 & 0.00 & 0.40 \\
\hline Assiut & - & - & - & - & 0.00 & 0.00 & - & - & - & - & 0.00 & 0.00 \\
\hline Siwa & - & - & - & - & - & 0.00 & - & - & - & - & - & 0.00 \\
\hline Ismailia & - & - & - & - & - & - & - & - & - & - & - & - \\
\hline
\end{tabular}

Table 12. Estimated similarity index between males and females of field populations of Bactrocera zonata compared to the laboratory strain using primer UBC-823 assessed by ISSR.

\begin{tabular}{|c|c|c|c|c|c|c|c|c|c|c|c|c|}
\hline \multicolumn{7}{|c|}{ Males } & \multicolumn{6}{|c|}{ Females } \\
\hline Strains & Lab. & Giza & KafrEl-sheikh & Assiut & Swia & Ismailia & Lab. & Giza & KafrEl-sheikh & Assiut & Siwa & Ismailia \\
\hline Laboratory & - & 0.00 & 0.00 & 0.00 & 0.00 & 0.00 & - & 0.00 & 0.40 & 0.00 & 0.00 & 0.29 \\
\hline Giza & - & - & 0.00 & 0.00 & 0.00 & 0.17 & - & - & 0.00 & 0.00 & 0.00 & 0.00 \\
\hline KafrEl-sheikh & - & - & - & 0.00 & 0.00 & 0.00 & - & - & - & 0.00 & 0.00 & 0.00 \\
\hline Assiut & - & - & - & - & 0.00 & 0.00 & - & - & - & - & 0.00 & 0.00 \\
\hline Siwa & - & - & - & - & - & 0.00 & - & - & - & - & - & 0.00 \\
\hline Ismailia & - & - & - & - & - & - & - & - & - & - & - & - \\
\hline
\end{tabular}

Table 13. Estimated similarity index between males and females of field populations of Bactrocera zonata compared to the laboratory strains using primer UBC-843 assessed by ISSR.

\begin{tabular}{lcccccccccccc}
\hline \multicolumn{9}{c}{ Males } & \multicolumn{1}{c}{ Females } \\
\hline Strains & Lab. & Giza & KafrEl-sheikh & Assiut & Swia & Ismailia & Lab. & Giza & KafrEl-sheikh & Assiut & Siwa & Ismailia \\
\hline Laboratory & - & 0.00 & 0.00 & 0.00 & 0.00 & 0.00 & - & 0.00 & 0.00 & 0.00 & 0.00 & 0.00 \\
Giza & - & - & 0.00 & 0.00 & 0.00 & 0.00 & - & - & 0.00 & 0.00 & 0.00 & 0.00 \\
KafrEl-sheikh & - & - & - & 0.00 & 0.00 & 0.29 & - & - & - & 0.00 & 0.00 & 0.00 \\
Assiut & - & - & - & - & 0.00 & 0.00 & - & - & - & - & 0.00 & 0.00 \\
Siwa & - & - & - & - & - & 0.33 & - & - & - & - & - & 0.00 \\
Ismailia & - & - & - & - & - & - & - & - & - & - \\
\hline
\end{tabular}


RAPD analysis detected a total of 176 fragments, with an average of 35.2 fragments per primer. The percentage of polymorphism ranged from $66.67 \%$ at primer $\mathrm{P} 13$ to $100 \%$ at primer $\mathrm{C} 16$. The polymorphic bands were 13 fragments, Table (14) with an average of 2.6 polymorphic bands per primer. The identified unique bands were 41 fragments with an average of 8.2 unique bands per primer. The number of amplified fragments varied from $7(\mathrm{C} 1)$, and $61(\mathrm{C} 18)$, the size of bands varied from $151 \mathrm{bp}$ (C18) to 591bp (C16). The number of bands detected by each primer depends on primer sequence and the extent of variation in specific genotype. High resistance levels between male flies strains of all areas compared to laboratory strain. In female flies, Siwa has the highest resistance level compared to both laboratory and other areas during RAPD-PCR. Seven monomorphic and thirteen polymorphic distinct fragments and 41 unique bands were obtained from RAPD technique. The polymorphic was 40 sharp fragments and 121 unique bands based on ISSR markers were detected. Five preselected RAPD primers and Five ISSR primers exhibited polymorphism among five different strains of $B$. zonata male and female flies were collected from five areas in Egypt such as Giza, Kafr-Elsheikh, Assiut, Siwa and Ismailia compared with laboratory strain as summarized in Table (14) and Fig. (1).

Table 14. Total number of monomorphic bands, polymorphic bands and percentage of polymorphism revealed by RAPD and ISSR markers in different field populations of Bactrocera zonata compared to the laboratory strain.

\begin{tabular}{|c|c|c|c|c|c|c|c|c|}
\hline Marker & Primer & $\begin{array}{l}\text { Mol. } \\
\text { Wt . } \\
\text { range }\end{array}$ & Frequency & $\begin{array}{c}\text { No. } \\
\text { of } \\
\text { band }\end{array}$ & $\begin{array}{l}\text { Unique } \\
\text { bands }\end{array}$ & $\begin{array}{c}\text { No. of } \\
\text { polymorphic } \\
\text { bands } \\
\end{array}$ & $\begin{array}{c}\text { No. of } \\
\text { monomorphic } \\
\text { bands }\end{array}$ & $\begin{array}{c}\% \\
\text { Polymorphism }\end{array}$ \\
\hline \multirow{7}{*}{ RAPD } & $\mathrm{C} 1$ & $206-573$ & 0.189 & 7 & 12 & 2 & 1 & 93.33 \\
\hline & P13 & $0.245-0.567$ & 0.389 & 13 & 6 & 0 & 3 & 66.67 \\
\hline & B12 & $0.170-0.474$ & 0.333 & 41 & 6 & 3 & 1 & 90.00 \\
\hline & $\mathrm{C} 16$ & $241-591$ & 0.235 & 54 & 6 & 5 & 0 & 100.00 \\
\hline & $\mathrm{C} 18$ & $151-377$ & 0.213 & 61 & 11 & 3 & 2 & 87.50 \\
\hline & Total & - & - & 176 & 41 & 13 & 7 & -- \\
\hline & Average & - & - & 35.2 & - & 2.6 & 1.4 & 87.5 \\
\hline \multirow{7}{*}{ ISSR } & UBC811 & 191-1033 & 0.147 & 34 & 22 & 12 & 0 & 100.00 \\
\hline & UBC-834 & $209-503$ & 0.105 & 31 & 23 & 8 & 0 & 100.00 \\
\hline & UBC849 & $188-852$ & 0.107 & 24 & 18 & 6 & 0 & 100.00 \\
\hline & UBC-823 & $133-792$ & 0.099 & 42 & 35 & 7 & 0 & 100.00 \\
\hline & UBC-843 & $231-736$ & 0.103 & 30 & 23 & 7 & 0 & 100.00 \\
\hline & Total & - & - & 161 & 121 & 40 & 0 & -- \\
\hline & Average & - & - & 32.2 & & 8 & 0 & 100.00 \\
\hline
\end{tabular}

Respecting five ISSR primers which were represented in Fig. (2), ISSR primers produced different numbers of DNA fragments of a total 161 bands (Table 14). 40 bands were polymorphic with an average of 8

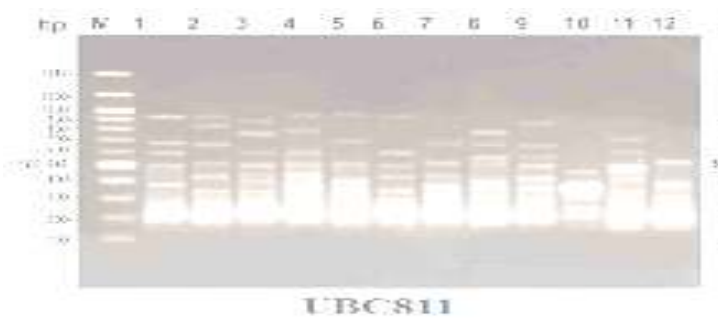
bands. The number of bands ranged from 24 (UBC849) to 42 (UBC-823), and the amplicon size varied from $133 \mathrm{bp}$ (UBC-823) to $1033 \mathrm{bp}$ (UBC811).
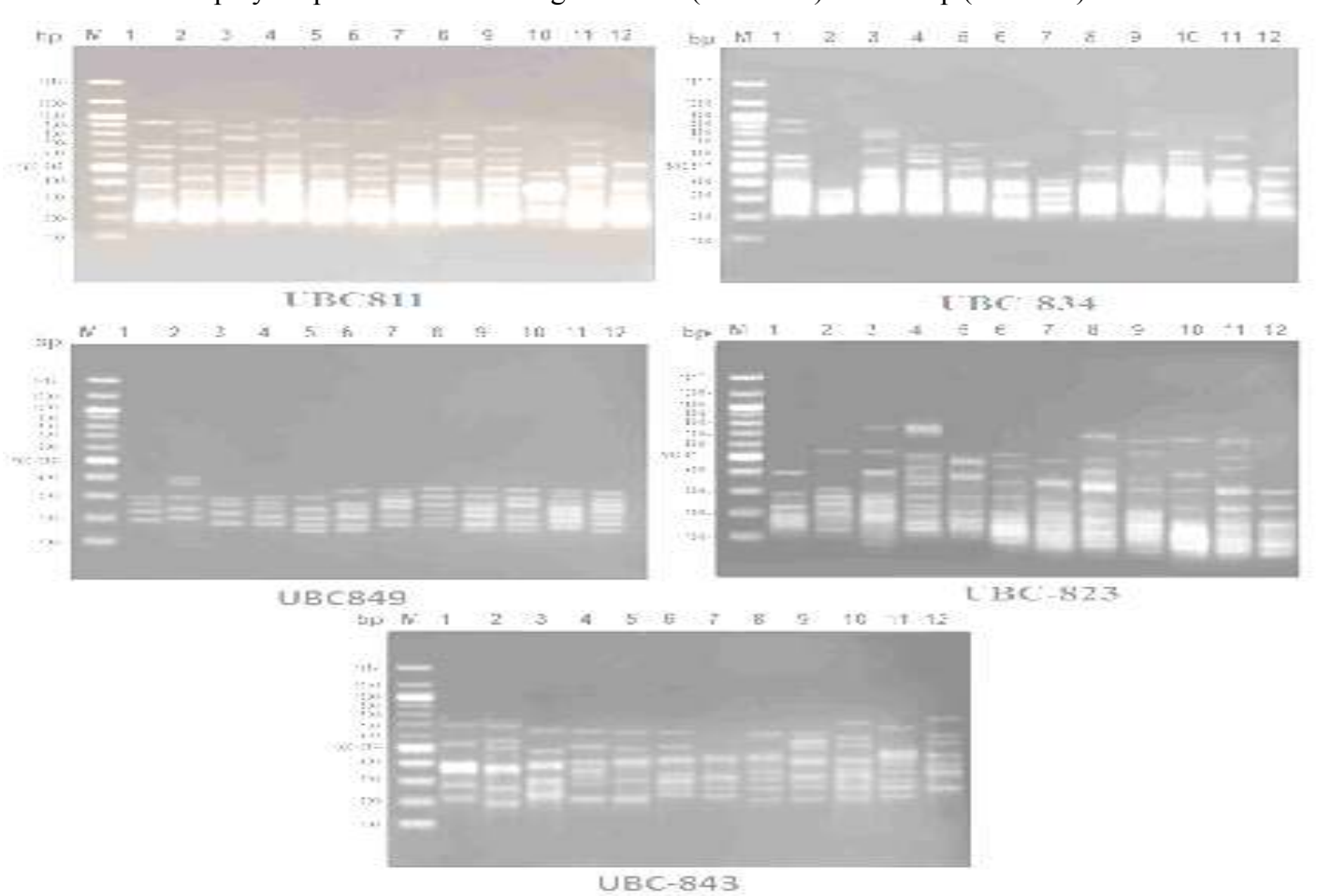

L $136:-823$

Fig.2. ISSR patterns and markers of Bactrocera zonata compared with laboratory strain. . marker (M); laboratory strain $(1,2)$; Giza $(3,4)$; Kfer-Elsheih $(5,6)$; Assiut $(7,8)$; Siwa $(9,10)$ and Ismailia $(11,12)$. 
Variation in DNA sequences produced polymorphism that indicated genetic diversity. In the present investigation, the study of genotypes of male and female $B$. zonata flies collected from different areas showed high level of polymorphism based on RAPD and ISSR bands. The percentages of the polymorphic fragments were $87.5 \%$ and $100 \%$, respectively.

Faleiro et al. (2000) mentioned that RAPD marker related to the resistance genes. Higher number of bands for each primer indicate larger genetic diversity among the genotypes under investigation (Agrama and Tuinstra, 2003). Primers with higher polymorphic bands are more efficient in studying genetic diversity and discrimination of the genotypes (Moghaddam et al., 2009). Laltanpuii et al. (2011) used RAPD as a dominant marker for fingerprinting of mosquito genome species, and found that genetic variance is the reason to be resistant. Patel et al (2014) studied the resistant of Plutella xylostella against rynaxypyr using RAPD-PCR, and found higher polymorphism; their results indicated that treatment of rynaxypyr created genetic alterations, subsequently, produced resistance in insects and, reported that RAPD profiles are an important molecular tool for distinguish between rynaxypyr- resistant and susceptible strains of Plutella xylostella at DNA level. Hassan and Mostafa (2000) found that the resistant ratio values ranged from 2.06 to 2.31 indicating tolerance in the field strains compared to laboratory strain. The present results are in agreement with Abu El-Seoud et al. (2005) who stated that resistance in Pectinophora gossypiella adults to the insecticide used ranged between 51.5 and $80.6 \%$ in the tested strains collected from four areas in Egypt. Our data are agreed with those published by Abu El-Seod et al. (2013), where they revealed that Ismailia field strain of $B$. zonata exhibited the highest resistance value to malatox toxicity. On the other hand, Qalubia field strain exhibited the lowest resistance level to malatox toxicity.

ISSR are semi-arbitrary markers amplified by using a single primer composed of a microsatellite repeated sequences (Hassein et al., 2003). These results agreed with Nadeem et al. (2014) who found that peach fruit fly have resistance to malathion in Pakistan; the resistance of $B$. zonata strains against malatox require management programs for returning the efficacy of insecticides based on control measures. ISSR markers offer higher reproducibility than RAPD due to the use of longer primers and higher annealing temperature. The choice of primers which used in ISSR amplification is critical for obtaining high levels of polymorphism. The PCR annealing temperature has a great impact on the pattern quality (Dušinsky et al., 2006).

In general, the results indicate that RAPD and ISSR bands gave adequate distinctions for studying insecticide malatox resistance in field and laboratory strains of $B$. zonata. Moreover, B. zonata flies collected from different field strains showed remarked higher resistance levels compared to laboratory strain. Isecticides must be applied in filed during pest outbrake time. So alternative insecticide from different groups used to avoid insecticide resistance. When there is a need to use insecticides wisely and according to the methods pre-scribed by the IPM (Integrated pest management) program.

\section{REFERENCES}

Abdel-Galil, F.A. (2007). Final report for the project no PS-FAI-020-03 entitled "Study on Biological Means for Controlling the Mediterranean Fruit fly Ceratitis capitata (Wiedemann) in New Valley Governorate" and submitted by the Academy of Scientific Research and Technology, Cairo, Egypt.

Abu-El-Seoud, S.; A.A. Kidr; Zahia, K.M.; A.M. Zaky and Faten, A.A. (2013). Monitoring resistance in different field strains of the peach fruit fly Bactrocera zonata (saund.) to malathion action in relation to biochemical aspects. Egypt. J. of Appl. Sci., 28 (10).

Abu-El-Seoud, S.; Emtithal, S.E.; M. Abdel-Samie and T.T. Abdel-Basset (2005). Toxicological and biochemical characterstics of certain insecticides on chlorpyrifos resistant strains of the pink bollworm Pectinophora gossypiella (Saunders) in Egypt. J. Egypt. Acad. Soc. Environ. Develop., 6(1): 63-89.

Agrama, H.A. and M.R. Tuinstra (2003). Phylogenetic diversity and relationships among sorghum accessions using SSRs and PAPDs. African Journal of Biotechnology, 2: 334-340.

Costa, R.; G. Pereira; I. Garrido; M.M. Tavares-de-Sousa and F. Espinosa (2016). Comparison of RAPD, ISSR, and AFLP molecular markers to reveal and classify orchardgrass (Dactylis glomerata L.) germplasm variations. PloS ONE, 11(4): e0152972.

Draz, K.A.A; A.G. Hashem; M.A. El-Aw and I.R. ElGendy (2002). Monitoring the changes in the population activity of peach fruit fly Bactrocera zonata (Saunders) at certain agro-ecosystem in Egypt. $2^{\text {nd }}$ International Conference. 1: 570-575.

Drew, R.A.I. (1989). Taxonomy and distribution of tropical and subtrobical Dacinae (Diptera Tephritidae). Pp: 9-14 Chapter 1.2. Fruit flies, their biology, Natural enemies and control. Vol. 3A.

Dukre, A.B.; M.P. Moharil; S.G. Basweshwar and N.G.V. Rao (2009). Role of glutathione-s-transferase in importing resistance to pyrethroids in Plutella xylostella (L). International J. Integrative Biology, 6(1): 17-21.

Dušinsky, R.; M. Kudela; V. Stloukalova and L. Jedlička (2006). Use of inter-simple sequence repeat (ISSR) markers for discrimination between and within species of blackflies (Diptera: Simuliidae). Biologia, Bratislava, Section Cellular and Molecular Biology, 61/3: 299-304.

El-Minshawy, A.M.; M.A. Al-Eryan and A.I. Awad (1999). Biological and morphological studies on the guava fruit fly $B$. zonata (Diptera: Tephritidae) found recently in Egypt. $8^{\text {th }}$ Nat. Conf. of Pests and Dis. Of Veg. and Fruits in Ismailia, Egypt.

EPPO (European and Mediterranean Plant Protection Organization) (2002). Report of EPPO Workshop on Bactrocera zonata. UNESCO, Paris, France.

Faleiro, F.G.; S. Wender; V.A.R. Vinhadelli; X.C. Ronan; A.M. Maurilio and G.D. Everaldo (2000). RAPD markers linked to a block of genes conferring rust resistance to the common bean. Genetics and Molecular Biology, 23(2): 399-402. 
Grewal, J.S.and C.S. Malhi (1987). Prunus persica batsch damage by birds and fruit fly pests in Ldhiana (Punjab). J. Entomol. Res., 11: 119-120.

Gunning, R.V.; C.S. Easton; L.R. Greenup and V.R. Edge (1984). Pyrethroid resistance in Heliothis armigera in Australia. J. Econ. Entomol., 77: 1283-1287.

Hashem, A.G.; S.M.A. Mohammed and M.F. El-Wakkad (2001). Diversity abundance of 728editerranean and fruit flies (Diptera: Tephritidae) in different horticulture orchards. Egyptian Journal of Applied Science, 16 (1): 303-314.

Hassan, A.I. and A.M. Mostafa (2000). Synergism the toxic action of some organophours insecticides against the Mediterranean fruit fly; Ceratitis capitata (Wied) larvae. Egypt. J. Appl. Sc., 15(11): 334-345.

Heckel, D.G.; L.J. Gahan; B.E. Tabashnik and M.W. Johnson (1995). Randomly amplified polymorphic DNA differences between strains of diamond back moth (Lepidoptera: Plutellidae) susceptible or resistant to Bacillus thuringensis. Ann. Entomol. Soc. Am., 88: 531-537.

Jain, S.K; B. Neekhra; D. Pandey and K. Jain (2010). RAPD marker system in insect study: A review. Indian Journal of Biotechnology, 9: 7-12.

Lalțanpuii, R.; Z. Rita; H. Tejmala; G. Gurusubramanian and N.S. Kumar (2011). RAPD-PCR characterization of insecticide resistant and susceptible Anopheles species. Sci. Vis., 11(3): 159-164.

Leroy, X.J. and K. Leon (2000). A rapid method for detection of plant genomic instability using unanchored-microsatellite primers. Plant Mol. Biol. Reporter, 18: 283a-283g.

Li, F. and N. Xia (2005). Population structure and genetic diversity of an endangered species, Glyptostrobus pensilis (Cupressaceae). Bot. Bull Sinica., 46: 155162.

Moghaddam, M.; A.M. Seyed; M. Nasser; T. Mahmoud; A. Saied and J. Farzad (2009). Assessment of genetic diversity in rapeseed cultivars as revealed by RAPD and microsatellite markers. African Journal of Biotechnology, 8(14): 3160-3167.
Moreau, S.C. (2014). A practical guide to DNA extraction, PCR, and gene-based DNA sequencing in insects. HALTERES, 5: 32-42.

Nadeem, M.K.; S. Ahmed; S. Nadeem; M. Ishfaq and M. Fiaz (2014). Assessment of insecticides resistance in field population of Bactrocera zonata (Saunders) (Diptera: Tephritidae). Journal of Animal \& Plant Sciences, 24(1): 172-178.

Nei, M. and Li, W.H. (1979). Mathematical model for studying genetic variation in terms of restriction endonucleases. Proc. Natl. Acad. Sci. USA, 76: 5269-5273.

Patel, N.N.; K.N. Patel and S. Vina (2014). Molecular characterization of rynaxypyr resistant Plutella xylostella (L). Genetics and Plant Breeding, 9 (2): 777-782.

Roush, R.T. and G.L. Miller (1986). Consideration for design of insecticide resistance monitoring programs. J. Econ. Entomol., 79: 293-298.

Sharma, S.; V.K. Dilwari and V.K. Gupta (2008). RAPDPCR analysis to monitor imidacloprid resistance in cotton whitefly. Resistance Pest Management Newsletter: 13.

Shehata, N.F.; M.W.F. Younes and Y.A. Mahmoud (2008). Biological studies on the peach fruit fly, Bactrocera zonata (Saunders) in Egypt. Journal of Applied Sciences Research, 1103-1106.

Shouhani, H.; D. Aboufazel; R. Rouhollah and Z. Mojtaba (2014). Application of ISSR to study the genetic diversity of honeybee (Apis mellifera L.) populations in some areas of Iran. J. BioSci. Biotech, 3(2): 127-131.

Welsh, J. and M. McClelland (1990). Fingerprinting genomes using PCR with arbitrary primers. Nucleic Acids Research, 18: 24.

Williams, J.G.K.; A.R, Kubelik; K.J. Livak; J.A. Rafalski and S.V. Tingey (1990). DNA polymorphisms amplified by arbitrary primers are useful as genetic markers. Nucleic Acids Res., 18: 6531-6535.

Yaqoob, R.; H.M. Tahir; S.Y. Khan and S. Naseem (2013). Insecticide resistance in Bactrocera zonata (Diptera: Tephritidae) in district, Sargodha, Pakistan. Biochem Pharmacol., 2: 114.

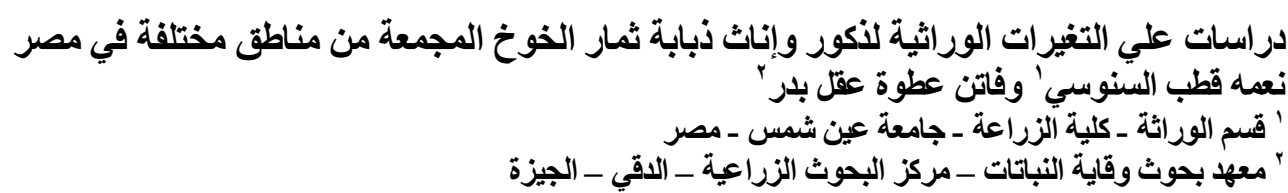

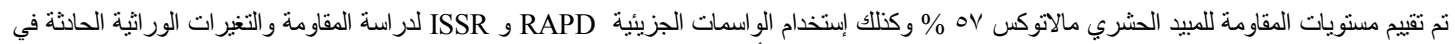

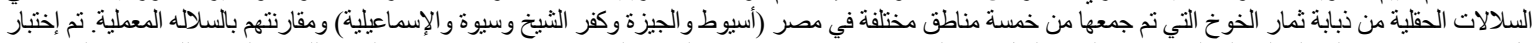

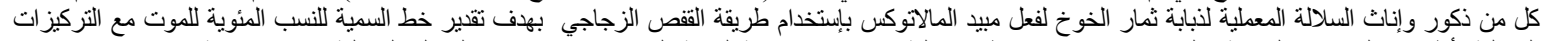

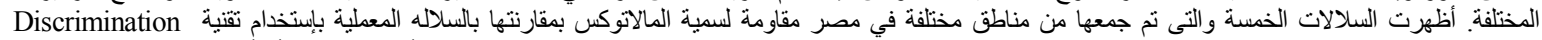
concentration

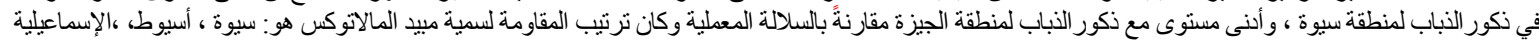

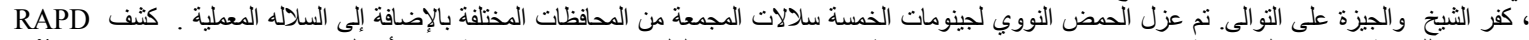

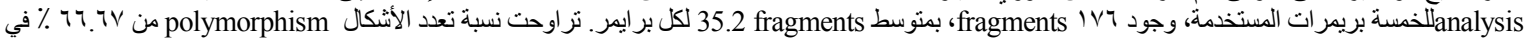

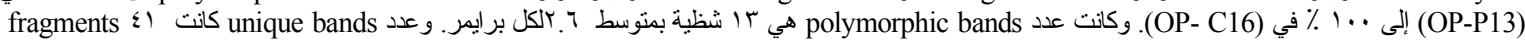

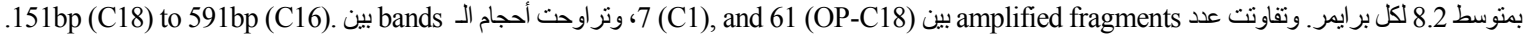

